\title{
PENGARUH POLA ASUH ORANG TUA TERHADAP MOTIVASI BELAJAR SISWA KELAS VII DI SMP KRISTEN 2 SALATIGA
}

\author{
Maulita Eka Yuliastuti ${ }^{1}$, Tritjahjo Danny Soesilo ${ }^{2}$, Yustinus Windrawanto ${ }^{3}$ \\ Email: maulitaeka571@gmail.com ${ }^{1}$, tritjahjo.danny@uksw.edu², \\ yustinus.windrawanto@staff.uksw.edu ${ }^{3}$ \\ Program Bimbingan dan Konseling Universitas Kristen Satya Wacana ${ }^{1,2,3}$
}

\begin{abstract}
This study aims to determine the significance of the effect of parenting patterns in the learning motivation of students grade VII in Christian Middle School 2 Salatiga. This type of research is comparative causal research or it can be called ex post facto research, this research carried out in Christian Middle School 2 Salatiga. Subject of this research subjects were class VII students, amounting to 87 people from class VII A totaling 22 students, class VII B totaling 21 students, class VII C totaling 22 students and class VII D totaling 22 students. The methods for collects the data is by spreading questionnaires about parenting pattern based on Baumrind's theory amounted to 30 questions, and learning motivation questionnaires based on Uno theory amounted to 25 questions. The data analysis technique used is simple linear regression with the help of the SPSS for Windows version 20. Computer program. Based on the results of the study there is no significant influence on parenting pattern towards the learning motivation of grade VII students in Christian Middle School 2 Salatiga, with parenting pattern only contributing influence of 3.9\% with Sig 0.097> 0.050 on learning motivation. While the remaining $96.1 \%$ is influenced by other factors not examined in this study.
\end{abstract}

Keyword: Parenting Pattern, Learning Motivation

\section{PENDAHULUAN}

Keluarga merupakan unit terkecil yang ada di dalam masyarakat. Bagi seorang anak, keluarga adalah sumber pendidikan anak yang pertama kalinya. Dalam keluarga itu anak akan diberi pendidikan oleh orang tua mengenai apa saja yang anak butuhkan untuk berinteraksi dan berkomunikasi dengan masyarakat sekitarnya. Karena itulah peran keluarga sangat penting dalam pengembangan pribadi anak.

Cara mendidik anak yang digunakan oleh orang tua di rumah biasanya disebut pola asuh. Pola asuh anak adalah cara, bentuk atau strategi pendidikan keluarga yang dilakukan keluarga dalam mendidik anaknya. Pola asuh orang tua ini banyak macamnya, dan setiap pola asuh yang diterapkan oleh orang tua dalam mendidik anaknya akan memiliki dampak masing-masing terhadap perkembangan anak kedepannya.

Pola asuh orang tua sangat berperan penting dalam pengembangan anak. Apabila orang tua menggunakan pola asuh yang tepat mereka terapkan dalam keluarga, maka akan membentuk pribadi anak yang diharapkan. Begitu pula apabila orang tua merasa acuh tak acuh dalam mendidik anaknya, maka akan berpengaruh juga pada pribadi anak di masa depannya.

Motivasi belajar merupakan semua daya penggerak dari dalam diri maupun luar seseorang yang nantinya akan menimbulkan kegiatan belajar. Motivasi 
belajar berperan sangat penting dalam hal memberikan semangat belajar bagi seseorang, seseorang yang mempunyai motivasi belajar tinggi akan mempunyai banyak energi untuk melakukan kegiatan belajar.

Beberapa penelitian yang telah dilakukan di antaranya oleh oleh Husna (2017) memberikan hasil sebesar 0,811 hal ini menunjukkan bahwa sebesar 81.1\% motivasi belajar (Y) dipengaruhi oleh pola asuh orang tua siswanya dan sebesar $18.9 \%$ dipengaruhi oleh faktor yang tidak diteliti. Penelitian yang dilakukan Hidayah (2012) menghasilkan $18,1 \%$ dipengaruhi oleh pola asuh orang tua dan $81,9 \%$ dipengaruhi oleh faktor lainnya. Hasil penelitian dari Harianti (2016) terdapat pengaruh yang signifikan dan positif antara pola asuh terhadap motivasi belajar siswa dengan nilai signifikan 0,000 dengan koefisien determinasi $69.1 \%$. pada penelitian yang dilakukan Prabasi (2017) memberikan kesimpulan bahwa ada pengaruh positif dan signifikan pola asuh orang tua terhadap motivasi belajar dan penelitian lain oleh Maulana (2018) menghasilkan 9,3\% pola asuh orang tua mempengaruhi motivasi belajar anak. Sedangkan penelitian yang dilakukan oleh Utami (2017) menyatakan bahwa tidak ada pengaruh yang signifikan pola asuh orang tua terhadap motivasi belajar siswa.

Beberapa penelitian yang dilakukan memberikan hasil bahwa pola asuh orang tua berpengaruh terhadap motivasi belajar anak. Namun disisi lain, terdapat penelitian yang memberikan hasil penelitian bahwa pola asuh tidak memperngaruhi motivasi belajar anak. Berdasarkan hasil penelitian terdahulu, peneliti saat ini ingin membuktikan apakah pola asuh orang tua dapat berpengaruh terhadap motivasi belajar anak atau pola asuh orang tua tidak berpengaruh terhadap motivasi belajar anak.

Selain itu, berdasarkan wawancara yang pernah peneliti lakukan dengan guru BK SMP Kristen 2 Salatiga, siswa dalam beberapa kelas di SMP tersebut memiliki motivasi belajar yang kurang. Hal ini terlihat pada saat pembelajaran berlangsung sebagian siswa kurang menunjukkan minatnya dalam proses pembelajaran. Peneliti juga melakukan wawancara dengan beberapa siswa, sebagian dari mereka menjawab bahwa mereka kurang memiliki motivasi dalam belajar karena mudah terganggu keadaan yang tidak kondusif saat belajar atau susah konsentrasi, sehingga belajar mereka menjadi tidak maksimal karena 
kurangnya motivasi belajar dalam diri masing-masing siswa.

Salah satu faktor yang dapat mempengaruhi motivasi belajar ini adalah keluarga yang dalam hal ini adalah pola asuh orang tua. Sikap orang tua yang terbuka dan selalu menyediakan waktu akan membantu anak dalam memahami dirinya yang terus mengalami perubahan juga akan membantu anak meningkatkan semangat belajarnya. Oleh karena itulah peran orang tua diperlukan dalam kegiatan belajar. Orang tua yang satu dengan yang lain memberikan pola asuh yang berbeda dalam membimbing dan mendidik anak-anaknya. Dari latar belakang keluarga yang berbeda akan membentuk pola asuh orang tua yang berbeda-beda dan diprediksikan dari pola asuh orang tua yang berbeda-beda itu dapat mempengaruhi motivasi siswa dalam belajar.

Sehubungan dengan pola asuh setiap orang tua yang dalam mendidik anak di rumah, yang pasti berbeda disetiap keluarga, peneliti ingin mengetahui apakah pola asuh yang diterapkan orang tua dalam keluarga yang berbeda akan berpengaruh terhadap motivasi belajar anak.

Tujuan dari dilakukannya penelitian ini adalah untuk mengetahui signifikansi pengaruh pola asuh orang tua terhadap motivasi belajar kelas VII di SMP Kristen 2 Salatiga.

\section{KAJIAN PUSTAKA \\ Pola Asuh Orang Tua}

Keluarga sangat berperan penting dalam pengembangan pribadi anak. Pola asuh yang digunakan oleh orang tua di rumah yang penuh kasih sayang dan pendidikan tentang kehidupan dapat digunakan sebagai sarana mempersiapkan anak agar nantinya bisa bersosialisasi di masyarakat dan sekitarnya dengan baik.

Dalam Padmomartono (2014) pola asuh orang tua adalah cara, bentuk, atau strategi pendidikan keluarga yang dilakukan orang tua kepada anak. Pembentukan pribadi anak yang positif tidak terlepas dari pola asuh anak yang diterapkan orang tua di dalam keluarga. Orang tua sebagai kepala keluarga mempunyai peran penuh untuk mengatur dan mendidik anaknya.

Diana Baumrind (Grobman, 2003 dalam Padmomartono, 2014) mendefinisikan pola asuh adalah perlakuan orang tua dalam memenuhi kebutuhan, memberi perlindungan dan mendidik anak dalam kehidupan seharihari.

Menurut penulis sendiri, pola asuh orang tua adalah suatu cara yang digunakan orang tua dalam mendidik anaknya di dalam keluarga itu. 
Menurut Diana Baumrind (Grobman, 2003 dalam Padmomartono, 2014) membagi pola asuh orang tua ke dalam tiga jenis, yaitu: 1) pola asuh otoriter, 2) pola asuh demokrtasi, dan 3) pola asuh permisif.

Pola asuh otoriter biasanya dengan cara memberitahukan anak untuk melakukan sesuai yang dikatakan dan diperintahkan oleh orang tuanya. Orang tua lebih banyak menghukum dan sangat mengendalikan anak.

Pola asuh demokratis memiliki gaya pengasuhan orang tua jenis ini adalah disiplin, ketat, tegas dan adil dengan menekankan pada pola komunikasi dengan anak serta memiliki harapan yang tinggi agar anak memiliki kematangan moral. Gaya pengasuhan ini sangat kurang menekankan hukuman fisik. Orang tua melibatkan anak dalam proses pengambilan keputusan dalam keluarga dan dalam menetapkan aturan yang mengikat di keluarga.

Pola asuh permisif memiliki aya pengasuhan orang tua jenis ini sangat longgar dan strukturnya tidak konsisten. Anak diberikan kebebasan luas dalam menetapkan kegiatan, aturan dan jadwal kegiatan. Anak lebih sering mengambil keputusan sendiri yang sebenarnya tidak nyaman untuk dilakukan oleh anak. Orang tua sedikit sekali menetapkan aturan dalam rumah tangga dan amat jarang menghukum anak.

\section{Motivasi Belajar}

Belajar merupakan kegiatan mental yang tidak dapat disaksikan dari luar. Apa yang sedang terjadi dalam diri seorang yang sedang belajar, tidak dapat diketahui secara langsung hanya dengan mengamati orang lain. Belajar pada manusia dirumuskan sebagai suatu aktivitas mental atau psikis, yang berlangsung dalam interaksi aktif dengan lingkungan, yang menghasilkan sejumlah perubahan dalam pengetahuanpemahaman, keterampilan dan nilaisikap. Perubahan itu bersifat secara relatif konstan dan berbekas (Winkel, 2012).

Dalam proses belajar, motivasi sangat diperlukan, sebab seseorang yang tidak mempunyai motivasi dalam belajar, tak akan mungkin melakukan aktivitas belajar. Maka dari itu motivasi belajar memiliki peran penting dalam kegiatan belajar seseorang.

Winkel (1983) di dalam bukunya menjelaskan motivasi belajar adalah keseluruhan daya penggerak di dalam diri seseorang yang menimbulkan kegiatan belajar, yang menjamin kelangsungan dari kegiatan belajar dan yang memberikan arah pada kegiatan belajar itu, maka tujuan yang dikehendaki oleh siswa tercapai. "Keseluruhan" yang 
dimaksud adalah karena biasanya terdapat beberapa motif yang bersamasama menggerakkan siswa untuk melakukan kegiatan belajar.

Motivasi dipandang sebagai dorongan mental yang menggerakkan dan mengarahkan perilaku manusia, termasuk perilaku belajar. Dalam motivasi terkandung adanya keinginan yang mengaktifkan, menggerakkan, menyalurkan dan mengarahkan sikap dan perilaku individu belajar (Koeswara, 1989; Siagian, 1989; Schein, 1991; Biggs $\&$ Telfer, 1987 dalam Dimyati, 2013).

Motivasi belajar menurut Uno (2006) adalah dorongan internal dan eksternal pada siswa-siswa yang sedang belajar untuk mengadakan perubahan tingkah laku, pada umumnya dengan beberapa indikator atau unsur yang mendukung. Dorongan internal siswa biasanya berasal dari dalam diri siswa itu sendiri, sedangkan dorongan eksternal dipengaruhi oleh keadaan dari luar diri siswa seperti keadaan sekitar tempat siswa belajar. Sardiman (2012) juga mengatakan motivasi belajar adalah keseluruhan daya penggerak dari dalam diri siswa yang menimbulkan keinginan belajar.

Berdasarkan beberapa pengertian motivasi belajar yang telah disebutkan di atas, peneliti dapat mengambil kesimpulan bahwa motivasi belajar adalah suatu keseluruhan daya penggerak atau pendorong baik dari dalam diri siswa atau dari luar yang menimbulkan keinginan belajar pada siswa. Dapat dikatakan keseluruhan karena memiliki beberapa motif atau penggerak yang membuat siswa berkeinginan untuk belajar.

Faktor yang dapat mempengaruhi motivasi belajar menurut Syamsu Yusuf (2009) ada 2, yang pertama adalah faktor internal meliputi faktor fisik (nutrisi atau gizi, kesehatan, dan fungsi panca indera) dan faktor psikologis (faktor yang berhubungan dengan aspek-aspek yang mendorong atau menghambat aktivitas belajar pada siswa). Faktor yang kedua adalah faktor eksternal berupa faktor sosial (yaitu merupakan faktor yang berasal dari manusia di sekitar lingkungan siswa) dan faktor non-sosial (yaitu merupakan faktor yang berasal dari keadaan atau kondisi fisik di sekitar siswa. Faktor ini meliputi keadaan udara (cuaca panas atau dingin), waktu (pagi, siang, atau malam), tempat (sepi, bising, atau kualitas sekolah tempat belajar), dan fasilitas belajar).

\section{METODE PENELITIAN}

Penelitian ini merupakan penelitian inferensial, penelitian inferensial merupakan suatu penelitian yang menguji 
hipotesis dan mengkaitkan antara satu variabel dengan variabel yang lainnya. Jenis penelitian yang digunakan adalah penelitian kausal komparatif atau dapat disebut juga penelitian ex post facto. Penelitian perbandingan kausal menentukan variabel-variabel yang menyebabkan terjadinya perubahan terhadap variabel-variabel yang dipengaruhi, maka dari itu penelitian ini terdapat dua variabel, yaitu variabel variabel bebas dan variabel terikat.

Variabel adalah segala gejala-gejala yang menunjukkan variasi, baik dalam jenis maupun tingkatannya. (Sutrisno Hadi, 1980: 260 dalam Darmadi, 2011). Variabel bebas adalah variabel yang dapat mempengaruhi atau menimbulkan variabel terikat. Variabel bebas (X) dalam penelitian ini adalah pola asuh orang tua. Variabel terikat adalah variabel yang dipengaruhi atau yang muncul karena adanya variabel bebas. Variabel terikat ini dilambangkan dengan variabel (Y). Variabel terikat (Y) dalam penelitian ini adalah motivasi belajar siswa kelas VII di SMP Kristen 2 Salatiga.

Penelitian ini akan dilaksanakan di SMP Kristen 2 Salatiga yang beralamat di Jl. Jendral Sudirman No. 111B RT 1 RW 1, Tingkir, Ledok, Argomulyo, Kota Salatiga, Jawa Tengah. Waktu yang digunakan untuk melakukan penelitian pada tanggal 24, 26, dan 29 Januari 2019. Populasi merupakan keseluruhan jumlah dari subyek penelitian yang akan diteliti. Populasi dari penelitian ini adalah 87 siswa kelas VII SMP Kristen 2 Salatiga. Sampel adalah sebagian yang diambil dari populasi yang representatif atau dapat mewakili populasi subjek penelitian yang bersangkutan. Pengambilan sampel dengan cara probabilitas sampling dengan teknik total sampling, maka semua siswa kelas VII SMP Kristen 2 Salatiga akan digunakan sebagai sampel.

Berikut adalah tabel dari populasi yang digunakan dalam penelitian ini:

Tabel 1. Daftar Deskripsi Subjek Penelitian

\begin{tabular}{|c|c|}
\hline Kelas & Jumlah \\
\hline VII A & 22 \\
\hline VII B & 21 \\
\hline VII C & 22 \\
\hline VII D & 22 \\
\hline Total & $\mathbf{8 7}$ \\
\hline
\end{tabular}

Berdasarkan tabel di atas dapat diketahui bahwa responden dari penelitian ini berasal dari siswa kelas VII SMP Kristen 2 Salatiga, di mana kelas VII A berjumlah 22 siswa, kelas VII B berjumlah 21 siswa, kelas VIIC berjumlah 22 siswa dan kelas VII D berjumlah 22 siswa, jumlah total siswa yang menjadi responden adalah 87 siswa. 
Dalam dalam penelitian ini peneliti menggunakan teknik penyebaran kuesioner kepada siswa guna mengumpulkan data penelitian. Kuesioner yang disebarkan kepada siswa adalah angket kuesioner pola asuh orang tua dan motivasi belajar. Sebelum angket digunakan dalam penelitian terlebih dahulu dilakukan uji validitas dan uji reliabilitas. Setelah diuji cobakan, item pertanyaan yang tidak valid dihapus dari angket karena sudah terwakili oleh item pernyataan yang lain. Selanjutnya angket yang sudah valid dan reliabel diperbanyak untuk digunakan dalam mengumpulkan data penelitian yaitu data perhatian orang tua dan motivasi belajar.

Untuk mengetahui adanya pengaruh atau tidaknya pola asuh orang tua terhadap motivasi belajar siswa dilakukan analisis menggunakan teknik analisis regresi linier sederhana. Teknik analisis regresi pada umumnya untuk menguji pengaruh satu variabel bebas terhadap variabel terikat, dalam teknik analisis ini juga dapat digunakan untuk mengetahui seberapa besar pengaruh variabel bebas memberi sumbangan terhadap keberadaan variabel terikat (Soesilo, 2018). Sebelum melakukan analisis data dilakukan uji prasyarat analisis terlebih dahulu. Analisis data dilakukan menggunakan bantuan komputer dengan program SPSS for Windows versi 20.

\section{HASIL DAN PEMBAHASAN}

Hasil Analisis deskriptif dalapm penelitian ini untuk menganalisis frekuensi pola asuh orang tua dan motivasi belajar siswa kelas VII SMP Kristen 2 Salatiga.

Berdasarkan hasil angket yang dibagikan, frekuensi pola asuh orang tua dapat dijabarkan sebagai berikut:

Tabel 2. Distribusi Frekuensi Pola Asuh Orang Tua Siswa

\begin{tabular}{|c|c|c|c|}
\hline No. & $\begin{array}{l}\text { Pola Asuh } \\
\text { Orang Tua }\end{array}$ & Frekuensi & $\begin{array}{c}\text { Persentase } \\
(\%)\end{array}$ \\
\hline 1. & Otoriter & 11 & 12,54 \\
\hline 2. & Permisif & 9 & 10,26 \\
\hline 3. & Demokratis & 67 & 76,38 \\
\hline & Total & 87 & $100 \%$ \\
\hline
\end{tabular}
frekuensi dapat diketahui bahwa pola asuh orang tua siswa demokratis adalah yang paling banyak sejumlah 67 dengen persentase 76,38\%. Dalam frekuensi tersebut terdapat pola asuh orang tua siswa yang bersifat otoriter sebanyak 11 siswa dan pola asuh orang tua siswa yang bersifat permisif sebanyak 9 siswa.

Berdasarkan hasil angket yang dibagikan, frekuensi motivasi belajar siswa dapat dijabarkan sebagai berikut:

Tabel 3. Distribusi Frekuensi Motivasi Belajar

\begin{tabular}{|c|c|c|c|}
\hline Kategori & Interval & $\begin{array}{c}\text { Frekue } \\
\mathrm{nsi}\end{array}$ & $\begin{array}{c}\text { Persen } \\
\text { tase } \\
(\%)\end{array}$ \\
\hline Sangat Tinggi & $82-100$ & 30 & 34,20 \\
\hline Tinggi & $63-81$ & 54 & 61,56 \\
\hline Cukup & $44-62$ & 3 & 3,42 \\
\hline Rendah & $25-43$ & 0 & 0 \\
\hline
\end{tabular}




\begin{tabular}{|c|c|c|}
\hline Total & 87 & 100 \\
\hline Min & \multicolumn{2}{|c|}{55} \\
\hline Max & \multicolumn{2}{|c|}{96} \\
\hline
\end{tabular}

Berdasarkan tabel 3 distribusi

frekuensi motivasi belajar dapat diketahui bahwa sebagian besar motivasi belajar siswa berada dalam kategori tinggi sebanyak 54 siswa dengan persentasi sebesar 62,046 \%. Dalam frekuensi tersebut terdapat 30 siswa memiliki motivasi belajar berkategori sangat tinggi, 3 siswa memiliki motivasi belajar berkategori cukup dan tidak ada siswa yang memiliki motivasi belajar berkategori rendah.

Hasil uji prasyarat yang berupa uji normalitas dan uji homogenitas. Pada uji normalitas menunjukkan hasil Kolmogorov Smirnov 0,237 untuk pola asuh orang tua dan signifikansi 0,237 di atas 0,05. Kolmogorov Smirnov 0,295 untuk motivasi belajar dan signifikansi 0,295 lebih dari 0,05. Dapat dinyatakan karena 0, $237>0,05$ dan 0,295 > 0,05, maka kedua data tersebut berdistribusi normal. Pada uji homogenitas nilai signifikansi yang didapat adalah 0,224, karena Sig. 0,225>0,05 maka dapat dinyatakan bahwa data tersebut bersifat homogen atau sama.

Berdasarkan hasil hasil analisis koefisien determinasi $\left(\mathrm{R}^{2}\right)$ pola asuh orang tua terhadap motivasi belajar diperoleh hasil sebagai berikut:
Tabel 4. Hasil Analisis Koefisien Determinasi $\left(\mathbf{R}^{2}\right)$ Pola Asuh Orang Tua Terhadap Motivasi Belajar

Model Summary

\begin{tabular}{|l|c|r|r|r|}
\hline Model & $\mathrm{R}$ & $\begin{array}{c}\mathrm{R} \\
\text { Square }\end{array}$ & $\begin{array}{c}\text { Adjusted R } \\
\text { Square }\end{array}$ & $\begin{array}{c}\text { Std. Error } \\
\text { of the } \\
\text { Estimate }\end{array}$ \\
\hline 1 &, $257^{\mathrm{a}}$ &, 039 &, 086 & 6,738 \\
\hline
\end{tabular}

a. Predictors: (Constant), polsuh2

Berdasarkan pada tabel 4 dapat diketahui bahwa nilai dari $\mathrm{R}$ square adalah 0,039 yang berarti 3,9\%. Jadi dapat dinyatakan bahwa variabel pola asuh orang tua memberikan kontribusi pengaruh terhadap motivasi belajar sebesar $3,9 \%$ dan untuk sisanya berjumlah $96,1 \%$ dipengaruhi oleh faktor lain yang tidak disebutkan dalam penelitian ini.

Hasil analisis regresi linear pola asuh orang tua terhadap motivasi belajar siswa diperoleh hasil sebagai berikut:

Tabel 5. Hasil Analisis Regresi Linear Pola Asuh Orang Tua Terhadap Motivasi Belajar

\begin{tabular}{|c|c|c|c|c|c|c|}
\hline \multicolumn{7}{|c|}{ ANOVA ${ }^{\mathrm{a}}$} \\
\hline \multicolumn{2}{|c|}{ Model } & Sum of Squares & $d f$ & Mean Square & $\mathrm{F}$ & Sig. \\
\hline & Regression & 127,981 & 1 & 127,981 & ,812 &, $097^{b}$ \\
\hline 1 & Residual & 6242,715 & 85 & 67,290 & & \\
\hline & Total & 6370.696 & 86 & & & \\
\hline
\end{tabular}

a. Dependent Variable: n4mobbel

b. Predictors: (Constant), polsun2

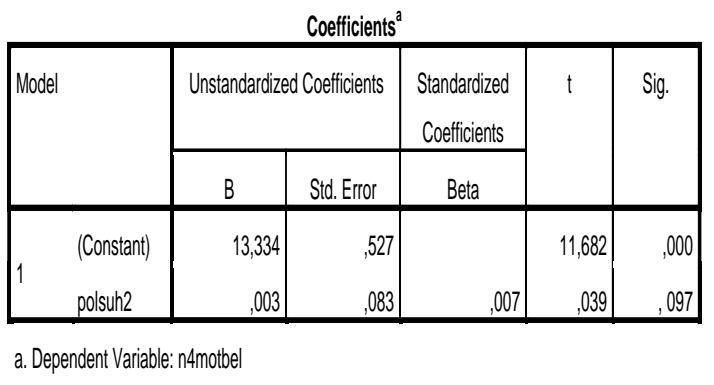


Berdasarkan data ANOVA pada tabel 4.6, hasil uji F hitung sebesar 0,812 dengan Sig. 0,097. Pengambilan keputusan hipotesis berdasarkan pada besarnya taraf signifikansi, apabila Sig. < 0,05 maka signifikan dan apabila Sig. > 0,05 maka tidak signifikan. Hasil penelitian menunjukkan bahwa Sig. = 0,097>0,05, dengan demikian dapat dinyatakan bahwa hasil tersebut tidak signifikan.

Data koefisien pada tabel di atas hasil uji t adalah $\mathrm{T}$ hitung pola asuh 0,039 dengan hasil Sig. 0,097. Hasil penelitian menunjukkan bahwa Sig. 0,097 > 0,05, dengan demikian dinyatakan bahwa tidak ada pengaruh yang signifikan pola asuh orang tua terhadap motivasi belajar.

Dari hasil analisis yang dilakukan, menunjukkan bahwa tidak adanya pengaruh yang signifikan pola asuh orang tua terhadap motivasi belajar siswa kelas VII di SMP Kristen 2 Salatiga dengan hasil uji $\mathrm{F}$ hitung sebesar 0,812 dengan Sig. 0,097, artinya 0,097 > 0,050. Hasil penelitian yang telah peneliti lakukan ini bertentangan dengan penelitian yang sudah dilakukan sebelumnya oleh Husna (2017), Hidayah (2012), Harianti (2016), Prabasi (2017) dan Maulana (2018), yang menyatakan adanya pengaruh yang signifikan pola asuh orang tua terhadap motivasi belajar siswa. Hasil penelitian ini mendukung penelitian yang dilakukan Utami (2017) yang menyatakan bahwa tidak ada pengaruh yang signifikan pola asuh orang tua terhadap motivasi belajar siswa.

Berdasarkan dari deskripsi data kategorisasi pada variabel pola asuh orang tua, dapat dilihat bahwa di SMP Kristen 2 Salatiga terdapat $12,54 \%$ pola asuh orang tua siswa bersifat otoriter, $76,38 \%$ pola asuh orang tua siswa bersifat demokratis dan $10,26 \%$ pola asuh orang tua siswa bersifat permisif. Pada variabel motivasi belajar, dilihari dari tabel distribusi frekuensi, tingkat motivasi belajar siswa di SMP Kristen 2 Salatiga yang memiliki kategori sangat tinggi $34,20 \%$, motivasi belajar siswa berkategori tinggi $61,56 \%$, motivasi belajar siswa berkategori cukup 3,42\% dan motivasi belajar siswa berkategori rendah terdapat $0 \%$. Hal ini dapat dinyatakan bahwa siswa kelas VII di SMP Kristen 2 Salatiga dominan memiliki motivasi belajar yang tinggi.

Menurut Baumrind (Grobman, 2003 dalam Padmomartono, 2014) mendefinisikan pola asuh adalah perlakuan orang tua dalam memenuhi kebutuhan, memberi perlindungan dan mendidik anak dalam kehidupan seharihari. Namun demikian pola asuh yang diterapkan orang tua dalam mendidikan 
anak dan membimbing anaknya tidak serta merta mempengaruhi motivasi belajar anak menjadi lebih tinggi atau pun lebih rendah.

Motivasi belajar menurut Uno (2006) adalah dorongan internal dan eksternal pada siswa-siswa yang sedang belajar untuk mengadakan perubahan tingkah laku, pada umumnya dengan beberapa indikator atau unsur yang mendukung. Dorongan internal siswa biasanya berasal dari dalam diri siswa itu sendiri, sedangkan dorongan eksternal dipengaruhi oleh keadaan dari luar diri siswa seperti keadaan sekitar tempat siswa belajar. Salah satu yang menjadi dorongan eksternal dari motivasi belajar anak adalah pola pengasuhan orang tua. Pola asuh orang tua dalam hal ini diperlukan agar anak didik mau belajar. Orang tua yang memberikan dorongan kepada anaknya untuk belajar akan membuat anaknya mau belajar dan mendapatkan apa yang menjadi tujuan akhirnya.

Namun, pola asuh orang tua tidak sepenuhnya menjadi pendorong seorang anak mau untuk belajar. Berdasarkan penelitian yang telah dilakukan oleh peneliti, sumbangan pola asuh orang tua dalam hal memotivasi anak dalam belajar hanya sebesar $3,9 \%$, sedangkan $96,1 \%$ lainnya berasal dari faktor lainnya yang tidak diteliti dalam penelitian ini. Hal ini dikarenakan pola asuh orang tua tidak terlalu menyentuh secara langsung terhadap aspek belajar anak. Pola asuh orang tua merupakan faktor eksternal motivasi belajar pada anak, sehingga kontribusi pengaruh pola asuh orang tua lebih sedikit dibandingkan faktor internal (dalam diri anak) dalam motivasi belajar seorang anak.

Faktor motivasi belajar lain yang tidak diteliti dalam penelitian ini menurut Syamsu Yusuf (2009) ada 2, yang pertama adalah faktor internal meliputi faktor fisik (nutrisi atau gizi, kesehatan, dan fungsi panca indera) dan faktor psikologis (faktor yang berhubungan dengan aspek-aspek yang mendorong atau menghambat aktivitas belajar pada siswa). Faktor yang kedua adalah faktor eksternal berupa faktor sosial (yaitu merupakan faktor yang berasal dari manusia di sekitar lingkungan siswa) dan faktor non-sosial (yaitu merupakan faktor yang berasal dari keadaan atau kondisi fisik di sekitar siswa. Faktor ini meliputi keadaan udara (cuaca panas atau dingin), waktu (pagi, siang, atau malam), tempat (sepi, bising, atau kualitas sekolah tempat belajar), dan fasilitas belajar).

\section{PENUTUP}

Berdasarkan penelitan yang telah dilakukan terhadap siswa kelas VII di 
SMP Kristen 2 Salatiga, maka disimpulkan bahwa tidak ada pengaruh yang signifikan pola asuh orang tua terhadap motivasi belajar siswa kelas VII di SMP Kristen 2 Salatiga. Pola asuh orang tua hanya memberikan kontribusi pengaruh sebesar 3,9\% dengan Sig 0,097 $>0,050$ terhadap motivasi belajar. Sedangkan sisanya sebesar $96,1 \%$ dipengaruhi oleh faktor lain yang tidak diteliti dalam penelitian ini.

Dari penelitian di atas, maka dapat dikemukakan saran-saran sebagai berikut: a. Bagi Siswa

Peneliti berharap kepada siswa di SMP Kristen 2 Salatiga agar bisa lebih termotivasi dalam belajar dan mengembangkan kemauan yang kuat dalam dirinya untuk belajar dengan mengembangkan kemampuan siswa dalam memahami pelajaran, memperhatikan kondisi siswa ketika belajar, dan kemauan dari dalam diri siswa untuk berhasil dalam belajar.

\section{b. Bagi Orang Tua}

Diharapkan bagi orang tua siswa untuk selalu berusaha mendampingi putraputrinya dalam hal belajar selama di rumah sehingga anak bisa lebih termotivasi dalam belajar, menyediakan fasilitas yang dibutuhkan anak dalam belajar dan memberikan apresiasi kepada anak mengenai hasil belajarnya sehingga anak akan lebih termotivasi dalam belajar.

\section{c. Bagi Guru BK}

Diharapkan bagi guru BK dapat terus memberikan dorongan atau motivasi di sekolah kepada siswa, memberikan bimbingan kepada siswa dalam hal belajar agar siswanya lebih termotivasi dan lebih semangat dalam belajar dan mengikuti mata pelajaran, serta memberikan sosialisasi kepada orang tua siswa mengenai pentingnya pendampingan orang tua menemani anak belajar.

d. Bagi Peneliti Selanjutnya

Diharapkan untuk peneliti selanjutnya dapat melakukan penelitian mengenai faktor-faktor lain yang dapat mempengaruhi motivasi belajar pada siswa.

\section{DAFTAR PUSTAKA}

Darmadi, Hamid. 2011. Metode Penelitian Pendidikan. Bandung: Alfabeta

Damyati. Mudjiono. 2009. Belajar dan Pembelajaran. Jakarta: Rineka Cipta

Garliah, Lili dan Fatma Kartika Sary Nasution. 2005. Peran Pola Asuh Tua dalam Motivasi Berprestasi. Psikologia Volume 1 Nomor 1, Juni 2005. Garliah, Lili dan Fatma Kartika Sary Nasution, 38 - 47. Tersedia di http://repository.usu.ac.id/handle/123 456789/15708 diakses pada tanggal 1 Oktober 2018 
Harianti, Rini dan Suci Amin. 2016. Pola Asuh Orang Tua dan Lingkungan Pembelajaran Terhadap Motivasi Belajar Siswa. Jurnal Curricula Volume I Nomor 2, Oktober 2016. Harianti, Rini dan Suci Amin, 20 29. Tersedia pada http://ejournal.kopertis10.or.id/index. php/curricula/article/view/983/236 diakses pada tanggal 1 Oktober 2018

Hidayah, Siti Tsaniyatul. 2012. Hubungan Pola Asuh Orang Tua dengan Motivasi Belajar Siswa Kelas V MI Negeri Sindulan Temon Kulon Progo. (Skripsi). Yogyakarta: Fakultas Tarbiyah dan Keguruan Universitas Islam Negeri Sunan Kalijaga

Husna, Robiatul. 2018. Pengaruh Pola Asuh Orang Tua Terhadap Terhadap Motivasi Belajar Siswa di SMP Negeri 14 Kota Jambi. (Skripsi). Jambi: Fakultas Keguruan dan Ilmu Pendidikan

Maulana, Rifqy. 2018. Pengaruh Pola Asuh Orang Tua Terhadap Motivasi Belajar di MTs Sunan Pandanaran Sleman Yogyakarta. (Skripsi). Yogyakarta: Universitas Islam Indonesia

Nursalim, Mochamad. Satingingsih, dkk. 2007. Psikologi Pendidikan. Surabaya: Unesa University Press

Padmomartono, Sumardjono. 2014. Konseling Remaja. Yogyakarta: Penerbit Ombak

Prabasari, Bonita dan Subowo. 2017. Pengaruh Pola Asuh Orang Tua dan Gaya Belajar Terhadap Prestasi Belajar Melalui Motivasi Belajar Sebagai Variabel Intervening. Economic Education Analysis Journal Volume 6 Nomor 2, Juni
2017. Prabasari, Bonita dan Subowo, 549 - 558. Tersedia di https://journal.unnes.ac.id/sju/index.p hp/eeaj/article/view/16442/8542 diakses pada 1 Oktober 2018

Pramawaty, Nisha dan Elis Hartati. 2012. Hubungan Pola Asuh Orang Tua dengan Konsep Diri Anak Usia Sekolah (10-12 Tahun). Jurnal Nursing Studies Volume 1 Nomor 1, 2012. Pramawaty, Nisha dan ELis Hartati, 87 - 92. Tersedia pada https://ejournal3.undip.ac.id/index.ph p/jnursing/article/view/187/193 diakses pada tanggal 1 Oktober 2018

Rahmawati, Rima. 2016. Faktor-Faktor yang Mempengaruhi Motivasi Belajar Siswa Kelas X SMA Negeri 1 Piyungan Pada Mata Pelajaran Ekonomi Tahun Jaaran 2015/2016. (Skripsi). Yogyakarta: Universitas Negeri Yogyakarta

Sugiyono. 2010. Metode Penelitian Pendidikan: Pendekatan Kuantitatif, Kualitatif, dan $R \& D$. Bandung: Alfabeta

Soesilo, Tritjahjo Danny. 2013. Psikologi Pendidikan. Salatiga: Griya Media

Soesilo, Tritjahjo Danny. 2018. Penelitian Inferensial dalam Bidang Pendidikan. Salatiga: Satya Wacana University Press

Suprapto. 2013. Metodologi Penelitian Ilmu Pendidikan dan Ilmu-Ilmu Pengetahuan Sosial. Yogyakarta: CAPS (Center for Academic Publishing Service)

Uno, H.B. 2007. Teori Motivasi \& Pengukurannya. Jakarta: Bumi Aksara 
Utami, Nabilah Kartiyasa. 2017. Hubungan Antara Pola Asuh Orang Tua dengan Motivasi Belajar. (Skripsi). Bandar Lampung: Universitas Lampung

Wijayanti, Isnaini. 2017. Hubungan Motivasi Belajar dengan Prestasi Belajar Siwa Kelas V SD Negeri 1 Waringinsari Barat Kabupaten Pringsewu. (Skripsi). Bandar Lampung: Fakultas Keguruan dan
Ilmu Pendidikan Universitas Lampung

Winkel, W.S. 2012. Psikologi Pengajaran. Yogyakarta: Media Abadi

Yusuf, Syamsu. 2009. Program Bimbingan dan Konseling di Sekolah. Bandung: Rizqi Perss 